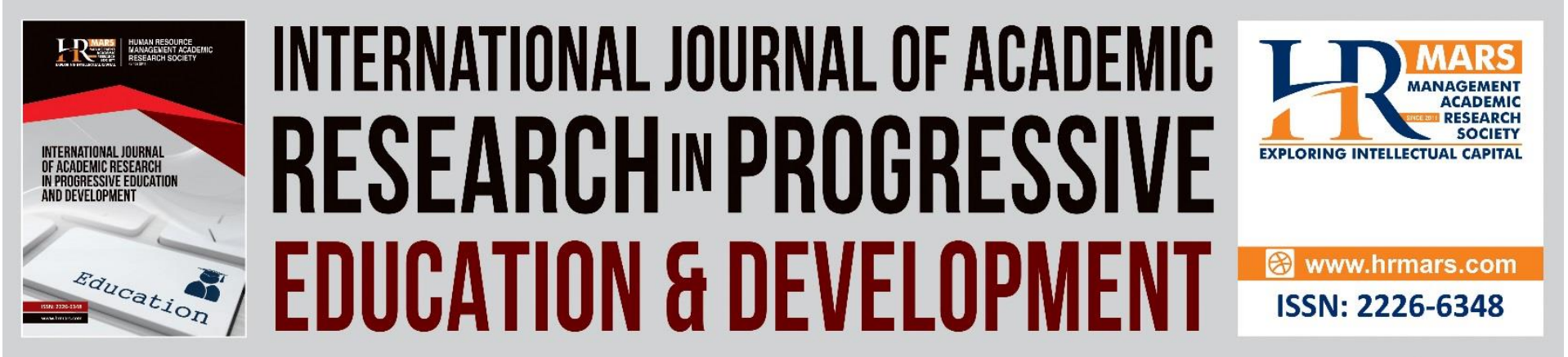

\title{
Improving Ethical Use of Information in Academic Writing among Polytechnic Students Using Online Plagiarism Module
}

\section{Dzatiah Mohamad, Aidah Abdul Karim}

To Link this Article: http://dx.doi.org/10.6007/IJARPED/v10-i3/10447

DOI:10.6007/IJARPED/v10-i3/10447

Received: 01 June 2021, Revised: 23 July 2021, Accepted: 17 July 2021

Published Online: 20 August 2021

In-Text Citation: (Mohamad \& Karim, 2021)

To Cite this Article: Mohamad, D., \& Karim, A. A. (2021). Improving Ethical Use of Information in Academic Writing among Polytechnic Students Using Online Plagiarism Module. International Journal of Academic Research in Pro, 10(3), 337-381.

Copyright: (C) 2021 The Author(s)

Published by Human Resource Management Academic Research Society (www.hrmars.com)

This article is published under the Creative Commons Attribution (CC BY 4.0) license. Anyone may reproduce, distribute, translate and create derivative works of this article (for both commercial and non-commercial purposes), subject to full attribution to the original publication and authors. The full terms of this license may be seen

at: http://creativecommons.org/licences/by/4.0/legalcode

Vol. 10(3) 2021, Pg. 373 - 381

Full Terms \& Conditions of access and use can be found at http://hrmars.com/index.php/pages/detail/publication-ethics 


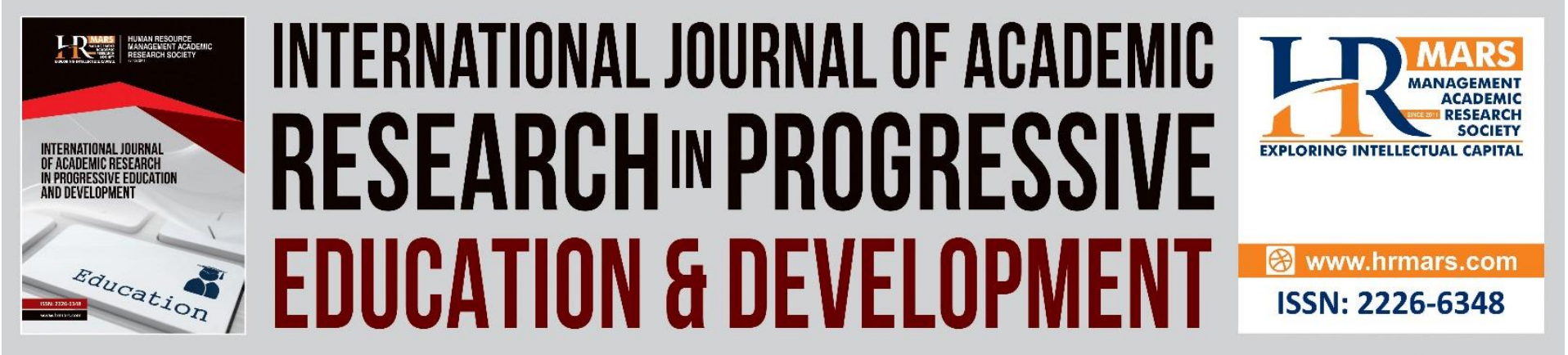

\title{
Improving Ethical Use of Information in Academic Writing among Polytechnic Students Using Online Plagiarism Module
}

\author{
Dzatiah Mohamad \\ General Studies Department, Politeknik Mukah, Sarawak \\ Email: dzatiah@pmu.edu.my \\ Aidah Abdul Karim \\ Faculty of Education, Universiti Kebangsaan Malaysia \\ Email: eda@ukm.edu.my
}

\begin{abstract}
Plagiarism has become a new challenge in higher learning in the information age. This study aimed to improve ethical use of information in academic writing among polytechnic students by implementing online plagiarism module in Ethics and Civilization Appreciation subject. The study employed an action research study and involved 30 Polytechnic students. Data was collected using previous students' assignments, interview and document analysis. The study found that the online plagiarism module implemented using online workshop had helped students to ethically use information and prepare references using a proper style in academic writing. This study implicated that any plagiarism modules for academic writing should be implemented within specific subjects to fully engage students in using information ethically in academic writing. The study also suggested the module could be implemented using online workshop which seem to add appeal to $Z$ generation of students.
\end{abstract}

Keywords: Plagiarism, Academic Writing, Ethical Writing, Higher Learning, Module

\section{Introduction}

Information literacy is a talent that entails the ability to locate and get knowledge in any format, as well as the active use of that information.. According to UNESCO (2004), information literacy is a set of abilities to recognize what and when information is needed, locate and critically select the information, use ethically and communicate it effectively (perpustakaan negara malaysia, 2019). According to (Forster, 2018) information literacy is important for creating new knowledge in learning and innovation. This includes the ability to process information and use information ethically so that the writing results are of better quality. Any education system, particularly higher education, that aims to create quality graduates who can meet industry needs and compete on a global scale, must strike a balance between knowledge and morals. 
In the context of Malaysia, the vision of producing graduates who are balance in knowledge and morality would support the fourth shifts in the Malaysian Higher Education Development Plan 2015-2025 (Malaysian Higher Education, 2015). The leaps outlined in the development plan are aimed at sustaining the development of knowledgeable and highly skilled human capital as well as the practice of an excellent work culture. The development plan drives the establishment of Polytechnic institutions that provide access to quality and recognized TVET programs and aim to produce quality Technical and Vocational Education and Training (TVET) graduates such as from polytechnics who are able to fulfill the industry needs and at the global level (Nugraha et al., 2020) .

In Malaysian polytechnics, The Appreciation of Ethics and Civilization subject was introduced in order to strengthen students' critical and analytical thinking to deal with a more challenging life. The subject was compulsory for semester one students and required students to produce academic writing at the end of the semester. However, it was found that previous students copy and paste works from internet and submit the works as their own. They also did not provide any citation in text and reference in their academic writing.

Therefore, this study aimed to improve ethical use of information and reference writing in academic writing among polytechnics students in Ethics and Civilization Appreciation subject by developing and implementing plagiarism online module. It is expected that the developed online plagiarism module would expose and train polytechnic students to use information in ethical way and write references using APA Style in academic writing.

\section{Literature Review}

Existing studies suggested that higher education students face the challenge of using information ethically when producing academic writing. Fatimah (2019) stated that students have problems in developing ideas, vocabulary, grammar and language expressions. A number of studies (Ali \& Othman, 2018; Mahamod \& Ismail, 2016) also found that the lack of vocabulary and being influenced by mother tongue makes it difficult for students to develop ideas in writing. Che Noh et al (2018) further found that students need to acquire skills to synthesize reading materials and require continuous assessment to ensure the academic writing produced by students are original and free from plagiarism elements. According to (Yu et al., 2018), academic misconduct activities such as cheating and plagiarism was performed by students who managed to obtain questions or answers from previous students. The students' own lazy habits, poor time management and incorrect use of paraphrase also contribute toward students' unethical use of information (Kaur et al., 2018). They also argued that the failure to detect and curb plagiarism activities among students would lead to students committing writing crime.

Other study by Pascal Iloh et al (2018) indicated that students were still vulnerable to fraud in writing after they were exposed to plagiarism issue. Pascal lloh et al (2018) conducted a study among Postgraduate trainees and fellows from Medical Colleges in Tertiary Health Institutions in Southeast Nigeria and found that plagiarism activities are commonly took place when students conducting independent project writing. Studies on postgraduate students on plagiarism, the forms of plagiarism that students commit and the reasons why such activities are done have also been made by (Selemani et al., 2018). They argued that on global scientific misconduct such as plagiarism can threaten integrity, research and the professional field. It can challenge the credibility, usability and reliability of graduates in the job market and any 
aspects of works performed by the graduates. This is also the case in Indonesia where students are only capable in knowledge, understanding and application but quite weak at a high-level thinking, and creative and critical thinking skills (Fitriyani \& Anggraini, 2018).

\section{Methodology}

This study employed an action research design. Action research involves the collection and translation of data to facilitate one's understanding of a phenomenon or problem in the workplace and is becoming an important tool for educators to improve their teaching and learning practice. This is possible because the main principle of action research is to improve one's practice or overcome the problems encountered by taking action on the findings found about a particular practice (Helfay, 2019).

In particular, this study employed a model of action research by Lewin $(1946 ; 1948)$. The model indicated that are four circular stages in action research known as plan, act, observed and reflect as illustrated in Figure 1. According to Lewin (1946), action research begins with the creation of a general idea and then data is collected to explain or unravel a situation. With this, an action plan can be produced to achieve the identified objectives along with a decision on the first steps that need to be taken. The next stage involves the collection of facts to monitor and evaluate the intervention, i.e. to act as a formative assessment. Lewin (1948) stated that all this can be created as a spiral process that contains planning, action, factfinding about the outcome of the action that has been taken.

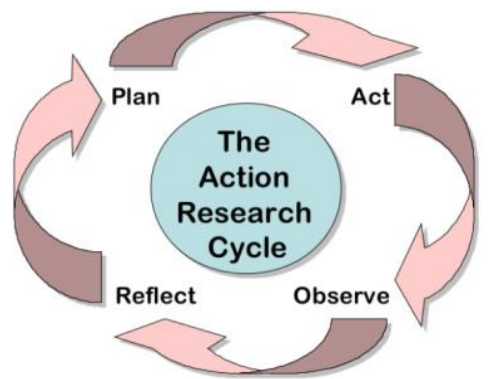

Figure 1: Action Research Model (Lewin, 1946)

The study was conducted in a polytechnic in Sarawak and involved 30 polytechnic students from the Department of Commerce. These students were selected because they undertook scholarly writing and was recommended by the course leader. The Plagiarism module was conducted in Ethics and Civilization Appreciation course in June 2020 session which requires students to conduct independent study as part of their learning assessment.

The Plagiarism module was conducted in an online workshop using Microsoft teams. The study have prepared the plagiarism module in the form of PowerPoint slides in order to facilitate students' understanding of plagiarism and to ease the implementation of the workshop. The plagiarism module also could be used as reference material for students after the workshop and help them to produce ethical academic writing. During the online workshop, students were exposed to format of academic writing, and ethical use of information and writing references using APA style in academic writing. students were exposed to paraphrasing, rearranging and how to write references at the end of writing using APA style. Exercises were also provided for students during the workshop on how to paraphrase and rearrange parts of original articles to prevent them from producing an exact 
copy of the articles and submitting it as their academic writing assignment. After two weeks of the implementation of the module, students were required to produce and submit an academic writing assignment. The assignment writing must fulfill the academic writing format, APA style reference writing and several techniques of paraphrasing as discussed in the online plagiarism workshop. To further facilitate students' writing process, the study has provided the students with a YouTube link as reference material.

The study used multiple data sources to collect data such as interview and document analysis before and after the online plagiarism module was implemented, observation during the module implementation, and students' evaluation form after the module was implemented. Before the plagiarism module was conducted, the study had interviewed ten of semester one students about their experience of producing academic writing. The study also conducted the document analysis on a sample of academic writing produced by the students before the module was implemented. The purpose of the document analysis was to identify mistakes made and issues faced by the students with regard to the use of information and reference writing in their academic writing.

The analysis provided input for the development of the plagiarism module as well provide a guidance for interviews with students after the module was implemented. The study also employed observation during the plagiarism module implementation. Specifically, the observation focused on how students prophase sentences and prepare references using APA style. The interviews were again conducted with 10 students after the plagiarism module was conducted. the purpose of this interviews were to examine students' knowledge on ethical use of information and reference writing in academic writing. Lastly the study used students' evaluation form to access student's view on the module implementation process and outcomes. The evaluation form consisted of 10 Likert scale items that enabled students to evaluate the process and outcomes of the online workshop in which the module had been implemented. The findings would help to undertake any necessary improvement measures for future workshop.

\section{Findings}

Data from interview and document analysis conducted before and after the implementation of the online plagiarism module showed that the online plagiarism module increase students' knowledge on academic writing format, and ethical use of information and reference writing in academic writing.

Interviews with students before the plagiarism module was implemented showed that although students have produced academic writing during their high school as well as in other courses at their polytechnic, they have insufficient knowledge on format of academic writing. The students also preferred to copy and paste works of others and submit the works as their own. For example, the students said that they had copied sentences from articles that they had obtained from google and used the sentences in their writing. Rather than not sending the work at all, they thought that it was better for them to submit the copied works to their lecturers. The interview also suggested that the lack of knowledge on plagiarism among students might be due to a lack of in -depth exposure from their subject teachers and lecturers. Accordingly, even though the students have continued their study as final year students at the polytechnic, they still do not understand the act and implication of plagiarism.

On the contrary, data from interview conducted after the online plagiarism module was implemented showed that students were able to use the correct language style and 
sentence instructions in their tasks. Besides that, to keep up with ethical writing behavior, the APA style was used for the citation and the appropriate reference style was also included.

Similarly, document analysis conducted by the study on a sample of academic writing produces by the students before the plagiarism module was implemented also indicated that students had minimal knowledge of developing ideas. Hence, they found challenges in manipulating words into grammatical sentences. Moreover, some of them were poor in performing language styles and sentence structures. In some cases, students were unable to use the appropriate format of citations and references. For the citation and the appropriate reference style was also included. In addition, most of the students did not provide any citation and references in their academic writing. While a few students did provide a few references in their writing, the references fail to follow a proper style for reference writing.

In contrast, after the module was implemented, the study found that the students have produced academic writing that follow an acceptable academic format. The students had also provided list of references at the end of their writing using correct APA style. Moreover, data from observation during the implementation of the module also suggested that students have acquire basic skills to paraphrase and rearrange parts of original articles in their academic writing that would prevent them from producing exact copies of the original articles. Finally, data from students' evaluation form indicated that the students perceive the implementation of the plagiarism module was able to improve their skills in using information in ethical ways and writing references using APA style in academic writing.

TABLE 1 : EXAMPLE OF STUDENT WRITING BEFORE USING THE ONLINE MODULE

\begin{tabular}{l|l} 
PENGENALAN & Types of \\
Kebelakangan ini amalan hidup berjiran seperti saling bertegur sapa, saling bantu membantu & Weaknesses \\
antara satu sama lain dan saling bertukar makanan sudah semakin dilupakan dalam kalangan & \\
masyarakat. Perkara ini berlaku disebabkan masyarakat sekarang hanya mengambil tahu hal & - No citation \\
masing-masing tanpa mengambil berat dan peduli tentang hubungan sesama jiran tetangga. & - No \\
Oleh yang demikian, kajian berkenaan konsep kejiranan dan muamalah sesama jiran & paraphrase, \\
tetangga yang dianjurkan dalam al-Quran dan al-Sunah amat perlu dilakukan. Ini dapat & copy paste \\
memberi impak dan kesedaran kepada masyarakat berkenaan konsep kejiranan yang sebenar & from internet \\
dan apakah rahsia di sebalik anjuran al-Quran dan al-Sunnah untuk berbuat baik sesame jiran & - No \\
tetangga. & References \\
Kajian kualitatif kepustakaan ini memberi fokus kepada konsep kejiranan dalam Islam, \\
hakhak jiran serta tingkatannya dan ayat al-Quran dan al-Sunnah yang menganjurkan berbuat \\
baik sesama jiran. & \\
& \\
TABLE 2 : EXAMPLE OF STUDENT WRITING AFTER USING THE ONLINE \\
MODUE
\end{tabular}




\section{TUJUAN PERLEMBAGAAN}

Perlembagaan sangat penting kepada sesebuah negara kerana ia boleh menjamin kewujudan dan peranan sesebuah negara. Tujuan perlembagaan diwujudkan ialah untuk mewujudkan pemerintahan yang adil. Menurut (Hambali, 2012) perkara ini dapat dibuktikan dari segi sejarah yang menunjukkan hak isitimewa orang melayu, Bahasa Melayu, agama Islam sebagai agama persekutuan dan sebagainya. Contohnya, walaupun agama Islam diwartakan sebagai agama rasmi persekutuan, namun dalam bahagian 1, perkara 3(1) agama lain bebas diamalkan oleh penganunya selagi tidak mengganggu gugat keamanan negara.

Selain itu, perlembagaan juga berperanan untuk mengelakkan penyalahgunaan kuasa dan mengawa pergerakan kerajaan dan rakyat. Rakyat juga bebas untuk bergerak manakala pemimpin juga diperuntukkan menggunakan kuasa sebaiknya (Muslim et al. (2013). Dengan demikian, ia boleh membentuk pembahagian kuasa dan dominasi kuasa oleh sesuatu pihak dapat diealkkan. Di dalam perlembagaan, beberapa peruntukan khas Yang di Pertuan Agong telah termaktub. Akan tetapi tindakan baginda masih termaktub di dalam perlembagaan walaupun telah diberi hak dan kuasa dalam perlembagaan.

\section{IMPROVEMENT}

- Include citation

- Include paraphrase, customize text from articles

- Include references

RUJUKAN

Hambali, K. M. K. @. (2012). Toleransi beragama dan Amalannya di Malaysia: Rujukan Kepada Artikel 11 Perlembagaan Persekutuan Malaysia. May, 125-139.

MUSLIM, NAZRI, JAMSARI ALIAS, WAN ZULKIFLI WAN HASSAN, AZIZI UMAR, N. Y. (2013). Analisis peruntukan orang Melayu dalam perlembagaan persekutuan Malaysia dalam konteks hubungan etnik. Jurnal Melayu, 11, 63-78.

TABLE 3: EFFECTIVENESS OF ONLINE WORKSHOPS USING ONLINE MODULE

\begin{tabular}{|c|c|c|c|c|c|c|c|c|c|c|c|c|c|}
\hline \multirow[b]{2}{*}{ Bil } & \multirow[b]{2}{*}{1} & \multirow{2}{*}{$\begin{array}{l}\text { Sangat } \\
\text { tidak } \\
\text { setuju }\end{array}$} & \multirow[b]{2}{*}{2} & \multirow{2}{*}{$\begin{array}{l}\text { Tidak } \\
\text { setuju }\end{array}$} & \multirow[b]{2}{*}{3} & \multirow{2}{*}{$\begin{array}{l}\text { Kurang } \\
\text { setuju }\end{array}$} & \multirow[b]{2}{*}{ Setuju } & \multirow{2}{*}{$\begin{array}{l}\text { Sangat } \\
\text { Setuju }\end{array}$} & \multicolumn{5}{|c|}{ BIL. RESPON } \\
\hline & & & & & & & & & 1 & 2 & 3 & 4 & 5 \\
\hline & \multicolumn{8}{|c|}{ Penilaian Penceramah. } & & & & & \\
\hline 1. & \multicolumn{8}{|c|}{ Objektif kursus tercapai } & 0 & 0 & 0 & 0 & 100 \\
\hline 2. & \multicolumn{8}{|c|}{ Kandungan kursus secta tugasan/latihan/bengkel yang sesuai } & 0 & 0 & 0 & 0 & 100 \\
\hline 3. & \multicolumn{8}{|c|}{ Penyampaian yang baik dan berkesan } & 0 & 0 & 0 & 0 & 100 \\
\hline 4. & \multicolumn{8}{|c|}{ Renggunaan alat bantuan mengajar dengan berkesan } & 0 & 0 & 0 & 0 & 100 \\
\hline & \multicolumn{8}{|c|}{ Renilaian pelaksanaan kursus } & & & & & \\
\hline 5. & \multicolumn{8}{|c|}{ Suasana tempat kursus yang kondusif } & 0 & 0 & 0 & 0 & 100 \\
\hline 6. & \multicolumn{8}{|c|}{ Perancangan dan perlaksanaan program telah dibuat dengan lancar } & 0 & 0 & 0 & 0 & 100 \\
\hline \multirow[t]{2}{*}{7.} & \multicolumn{8}{|c|}{ Masa yang diperuntukan bagi setiap modul adalah sesuai } & 0 & 0 & 0 & 10 & 90 \\
\hline & \multicolumn{8}{|c|}{ Renilaian keberkesanan kursus terhadap pesecta } & & & & & \\
\hline 8. & \multicolumn{8}{|c|}{ Reningkatan pengetahuan/pemahaman berbanding sebelum ini } & 0 & 0 & 0 & 30 & 70 \\
\hline 9. & \multicolumn{8}{|c|}{$\begin{array}{l}\text { Lebih berkexakinan mengajac modul berkenaap/menjalankan tugas } \\
\text { beckaitan/mengaplikasi apa yang dipelajari berbanding sebelum ini }\end{array}$} & 0 & 0 & 0 & 40 & 60 \\
\hline 10. & \multicolumn{8}{|c|}{ Pada keseluruhannya latihan/kursus ini adalah beriaya dan bermanfaat. } & 0 & 0 & 0 & 0 & 100 \\
\hline & \multicolumn{8}{|c|}{ JUMLAH RESPON } & & & & & \\
\hline & \multicolumn{3}{|c|}{ Keberkesanan } & \multicolumn{3}{|c|}{$\begin{array}{l}\text { Tidak Berkesan } \\
\text { (Skor } 1 \text { \& 2) }\end{array}$} & \multicolumn{2}{|c|}{$\begin{array}{c}\text { Kurang Berkesan } \\
\text { (Skor 3) }\end{array}$} & \multicolumn{5}{|c|}{$\begin{array}{l}\text { Berkesan } \\
\text { (Skor } 4 \text { \& 5) }\end{array}$} \\
\hline \multicolumn{4}{|c|}{ JUMLAH RESPON } & \multicolumn{3}{|c|}{0} & & 0 & & & 100 & & \\
\hline Ulas & $\operatorname{anc} U$ & RUSETIA & RLP & & & & & Peratus s & & & $\begin{array}{l}\text { kes } \\
\%\end{array}$ & & \\
\hline
\end{tabular}

\section{Discussion}

The study indicated that students are needed to be exposed to ethical aspects of academic writing at the same time they are exposed to format of academic writing. similar to 
existing studies such as by Alhadlaq et al. (2020), the study showed that students must be guided to produce academic writing with proper format as well to use information ethically and develop references using a proper style in the academic writing.

This study showed that the development and implementation of plagiarism module for academic writing within specific subjects had helped students to engage in the process of developing academic writing, and ethical use of information and developing references using a proper style for academic writing. The developed module would have exposed students to various ways of paraphrasing sentences from various information sources and thus would prevented them from engaging in plagiarism activities.

The study suggested that it is necessary for higher learning institutions to develop plagiarism module for academic writing for their students in order to prevent the students to engage in any forms of plagiarism activities. Moreover, the study implicated that the module must be implemented within specific subjects to ensure full students' engagement and commitment in the process of ethical use of information in academic writing. The study also suggested that the module could be implemented using online workshop which would offer flexibility to students in term of time and location as well as add appeal to $Z$ generation of students.

\section{Conclusion}

This study aimed to improve students' ethical use of information and reference writing in academic writing by developing and implementing online plagiarism module. The study found that the module helps students to develop academic writing with an acceptable format, and use information ethically and develop references using a proper style in academic writing. This study implicated that any plagiarism modules for academic writing should be implemented within specific subjects to fully engage students in using information ethically in academic writing. The study also suggested the module could be implemented using online workshop which seems to add appeal to $Z$ generation of students.

The findings in this study can be an assessment guide for academic writing modules to benefit Malaysian Polytechnic students. Therefore, this study suggests that the construction of academic writing modules is adapted from this study. It can be used as a formative guide for students that can be used either for teacher or self-assessment.

\section{References}

Alhadlaq, A. S., Dahmash, A. Bin., \& Alshomer, F. (2020). Plagiarism perceptions and attitudes among medical students in Saudi Arabia. Sultan Qaboos University Medical Journal, 20(1), e77-e82.

Ali \& Othman, Y. (2018). Strategi pembelajaran kemahiran menulis bahasa Melayu sebagai bahasa kedua dalam kalangan pelajar Melanau daerah Daro. Jurnal Pendidikan Bahasa Melayu, 8(Mei), 33-41.

Che Noh, M. A., Mohamad, N., Abd Halim, A. H., \& Abu Bakar, A. A. (2018). Perlaksanaan Kaedah Pembelajaran Berasaskan Projek dalam Pengajaran dan Pembelajaran Kaedah Fiqh. Journal of Quran Sunnah Education \& Special Needs, 2(2), 14-23.

Fatimah, N. (2019). Students' Needs for Academic Writing at the English Education Department. English Language Teaching Educational Journal, 1(3), 161.

Fitriyani, L. O., \& Anggraini, W. (2018). Project Based Learning : Pengaruhnya Terhadap Keterampilan Proses Sains Peserta Didik Di Tanggamus Project Based Learning: The 
Effect On Student ' S Science Processes Skills In Tanggamus Indonesian Journal of Science and Mathematics Education, 01(November), h. 243-253.

Forster, M. (2018). information literacy's role in worplace competence, best practice.

Helfaya, A. (2019). Assessing the use of computer-based assessment-feedback in teaching digital accountants. Accounting Education, 28(1), 69-99.

Kaur, M., Singh, M., \& Ganapathy, M. (2018). Social Sciences \& Humanities Understanding Plagiarism from the Lens of First Year Tertiary Level Students. Pertanika J. Soc. Sci. \& Hum, 26.

Lewin, K. (1946). Action Research and Minority Problems. Journal of Social Issues, 2, 34-46.

Mahamod, \& Ismail. (2016). Sikap Dan Kesediaan Pelajar Sekolah Menengah Terhadap Kemahiran Berfikir Aras Tinggi Dalam Pembelajaran Komsas Bahasa Melayu. Jurnal Pendidikan Bahasa Melayu, 6(2), 59-67.

Nugraha, H. D., Kencanasari, R. A. V., Komari, R. N., \& Kasda, K. (2020). Employability Skills in Technical Vocational Education and Training (TVET). Innovation of Vocational Technology Education, 16(1), 1-10.

Iloh, P. G., Amadi, A., Chukwuonye, M., \& Godswill-Uko, E. (2018). Plagiarism in a resourceconstrained context: A cross-sectional study of post-graduate medical college trainees and fellows in a tertiary health institution in South East Nigeria. Archives of Medicine and Health Sciences, 6(2).

perpustakaan negara malaysia. (2019). panduan literasi media dan makluamat.

Selemani, A., Chawinga, W. D., \& Dube, G. (2018). Why do postgraduate students commit plagiarism? An empirical study. International Journal for Educational Integrity, 14(1).

Yu, H., Glanzer, P. L., Johnson, B. R., Sriram, R., \& Moore, B. (2018). Why college students cheat: A conceptual model of five factors. Review of Higher Education, 41(4), 549-576. 